\title{
Quality of Urban Green Open Space Based on Urban Surface Temperature for Anticipation of Urban Heat Island (Case Study: Green Open Space Kendari City)
}

\author{
Arief Saleh Sjamsu' ${ }^{1}$, Irma Nurjannah ${ }^{2}$, I Made Krisna Adhi Dahrma ${ }^{3}$, Dwi Rinnasuri \\ Nuroduola ${ }^{4}$ \\ \{ariefslhsjamsu@gmail.com ${ }^{1}$, nurjannah.irma@gmail.com², krz.vista@gmail.com ${ }^{3}$, \\ mailto_drnoraduola@yahoo.com ${ }^{4}$ \}
1,2,3 Department of Architecture, Laboratory of Architecture planning and design, Faculty of Engineering, Halu Oleo University, Kendari, Indonesia
${ }^{4}$ Department of Architecture, Laboratory of Residensials and Housing, Faculty of \\ Engineering, Halu Oleo University, Kendari, Indonesia
}

\begin{abstract}
The availability of green open space (GOS) in Kendari has crucial role as social and economic function besides its ecological function for an urban area. Along with the population growth and the increasing land use for construction site, a new problem emerged namely the decreasing of green open space and its quality for years. However, It is known that green open space have a positive contribution to the development of urban heat island (UHI). This study aims at investigating the quality of urban GOS in Kendari through Urban Surface Temperature as the effort of anticipating the form of urban heat island effect. This study applied quantitative and qualitative design with survey approach toward the area of GOS. Quantitative analysis was used to measure the area and quality of GOS and GIS software was used to obtain data of Urban Surface Temperature from urban GOS to GOS in Sub Regency level in Kendari, while qualitatively, the data was used to indicate the quality of GOS toward the aspect of urban heat island formation. From the results of this study, it is known that the surface temperature in Kendari strongly influenced by the wide availability of green open space as a cooling surface temperature. The wider and better condition of green open space, the cooler of surface temperature and vice versa. It is also known that the District of West Kendari is a sub-district that has the smallest urban green open space of $1,6 \mathrm{~km}^{2}$ or $9,4 \%$ of the total area of the sub-district so, the tendency of surface temperatures in urban environments is higher.
\end{abstract}

\section{Keywords: Quality of Green Open Space (GOS), Urban Heat Island, Urban surface} temperatur.

\section{Introduction}

Kendari is one of the developing cities with a vision and mission as a livable city. The livable city in question is a condition that describes Kendari, where the community can live comfortably, calmly, prosperously, healthily, safely, safely and peacefully in the city and can provide opportunities for all urban community activities with an ecological system [1]. The existence of green open spaces is very important in supporting the formation of livable cities in Kendari. The existence of these green open spaces is very important because it can maintain the sustainability of urban ecosystems such as the hydrological cycle, micro-climate, reduce 
pollution, produce oxygen in the air which is beneficial for health. The existence of even green open spaces can create harmony between the natural environment and the built environment that is useful for the social interests of the community such as interacting and expressing and relaxing in order to create a livable and sustainable city.

Conditions and extent Existing green open spaces in Kendari are known by conducting field surveys and synchronizing data from related agencies including reviewing Kendari RTRW to obtain information on existing green open space conditions in both the entire city and the open green space of the sub-districts. Kendari is a city that has grown and developed with an increase in population growth rate of $9 \%$ in 2016. The increase in population plus an increase in land use conversion from open space to buildings has become a problem in Kendari. The increase in land use as the largest building is located in Kadia Subdistrict with the designation as an office complex area. The increase in the number of buildings without the provision of green space in these densely populated areas has caused the temperature of the area to be higher when compared to other regions which have adequate green space and wide area. With the increasing surface temperature, the user's comfort level in particular the thermal conditions of the area becomes uncomfortable.

This study basically wants to identify the quality of green space by looking at the condition and extent of urban green open space in Kendari by using Urban surface temperature methods so that it can be compared between the results of mapping the surface temperature with the shape of the urban heat island. So that later it can be known that the subdistricts have the lowest RTH area and have the highest surface temperature which can later be planned for the provision of new RTH to cool the area so that the urban heat island effect is reduced.

\section{Theoritical Review}

Physically, the development of a city can be seen from its growing population and increasingly dense, its buildings are increasingly tightly packed and build-up areas, especially settlements that tend to be wider, and more complete urban facilities that support the city's social and economic activities [2]. Changes in land use that occur in developing cities to large cities in turn cause the formation of conditions for urban heat islands in the city far higher than the surrounding area, this condition is better known as urban heat island. Hot poles are formed if some vegetation is replaced by asphalt and concrete for roads, buildings and other structures needed to accommodate high population growth. The replaced soil surface will absorb more of the sun's heat and reflect it so that the urban heat islands in the city rise. This will affect the condition of air quality, human health and will also affect the energy use in the city [3]. High temperatures were characteristic of the urban air condition, thus created a city microclimate [4]. The temperature difference between the city and the surrounding area is called Urban Heat Island (UHI) [5] gives an influence on the comfort level of the city, was an example of climate modification that accidentally happened due to human activities [3]. Many actors influence the occurrence of UHI phenomena. In general these factors include meteorology, location, and characteristics of the city. 


\section{Research Metdhod}

In this study, the Mixed-method was conducted, used qualitative and quantitative methods with a comparative approach. Qualitatively a survey was conducted on the condition and extent of urban green open space in Kendari up to per District and collected data on the area of green open space from related agencies and reviewed the latest RTRW of Kendari. Quantitative analysis method was used to determine the existing green open area of the subdistrict based on the results of a field survey and mapping the surface temperature per subdistrict with the help of GIS software based on urban surface temperature methods. Then the results of the qualitative analysis of the conditions and quality of green open space were described by comparing with the green open space data measured by surface temperature while describing the effects and effects on the Urban Heat Island (UHI) forming effect.

\section{Analysis and Discussion}

\section{a. Availability of Green Open Space in Each Sub-District in Kendari}

Based on Minister of Public Works Regulation number 5 of 2008 concerning Guidelines for Provisioning Urban Green Open Space, it was stated that the proportion of green open space in an urban area is at least $30 \%$ consisting of $20 \%$ public green open space and $10 \%$ private green open space. Based on the survey results on the conditions of green open space in Kendari, which was an urban green open space, both located in the city center and located in suburban areas, which in this case did not include protected forests and conservation areas, it was known that the total area of space Green openings in Kendari reached $170.7 \mathrm{~km}^{2}$ with an area of $63.17 \%$ of the total area of Kendari. This meant that overall the area of green open space in Kendari was still within a very adequate limit because more than the minimum requirement of $30 \%$ was required by law. From table 1, it was known that the largest area of urban green open space was in the District of Baruga with a percentage reaching $85.3 \%$ of the total area of the sub-district. Then followed respectively by the District of Puuwatu with a percentage of $85.1 \%$ and Abeli District which was $76.8 \%$. Whereas Districts that had a percentage of green open space less $30 \%$ were in West Kendari District which had a green open space of $9.4 \%$ of its total area. For the area of green open space in the other sub-districts, the percentage was still above $30 \%$ as shown in Figure 1. The total percentage of public green open space in Kendari was $57.18 \%$ while private RTH was $42.82 \%$ of the total open space of $170.7 \mathrm{~km}^{2}$ or $59.10 \%$ of the total area of Kendari. This could be interpreted that the requirement for the proportionality of the distribution of $30 \%$ green open space had been fulfilled even more for the whole city of Kendari, which was more than $20 \%$ for public green open spaces. Similarly, the private green open space was greater than $10 \%$ of the required area, reaching $42.82 \%$, but not in the sub-district scale, where Kadia District had a percentage of green open space less $30 \%$. From this structure it could be seen that the proportion of public green open space in Kendari was still more dominant than private green open space.

Table 1. Percentage of Green Open Space based on sub districts in Kendari 2018

\begin{tabular}{lccc}
\hline Sub Districs & $\begin{array}{c}\text { Area } \\
\left(\mathrm{km}^{2}\right)\end{array}$ & $\begin{array}{c}\text { Green Open Space } \\
\left(\mathrm{km}^{2}\right)\end{array}$ & $\begin{array}{c}\text { Percentage } \\
(\%)\end{array}$ \\
\hline Abeli & 42,7 & 32,8 & 76,8 \\
\hline
\end{tabular}




\begin{tabular}{lccc}
\hline Baruga & 45,7 & 38,9 & 85,3 \\
Kadia & 8,4 & 1,9 & 23,4 \\
Kambu & 23,1 & 14,4 & 62,6 \\
Kendari Barat & 19,6 & 1,6 & 9,4 \\
Poasia & 40,3 & 17,8 & 44,2 \\
Wua-wua & 10,7 & 9,8 & 91,9 \\
Puuwatu & 43 & 36,7 & 85,1 \\
Kendari & 16,1 & 5,1 & 31,7 \\
Mandonga & 20,61 & 11,7 & 54,2 \\
\multicolumn{1}{c}{ Total } & 270,21 & 170,7 & 63,17 \\
\hline Source : Kendari Green Open Space Survey, 2018
\end{tabular}

Based on the survey results it was known that the area of green open space in Baruga Subdistrict is $38.96 \mathrm{~km}^{2}$ and is the sub-district that has the largest green open space in Kendari, followed by Puuwatu District $36.70 \mathrm{~km}^{2}$ and Abeli District $32.81 \mathrm{~km}^{2}$. The high percentage of green open space in Baruga sub-district was supported by the existence of green open spaces of production forests and extensive plantation and agricultural areas. Area of green open space in the District of Puuwatu was dominated by public green open spaces. Whereas in Abeli District is influenced by the extent of public and private green open spaces.

For West Kendari Sub district, which had the smallest percentage of urban green open space (excluding protected and conservation forests), which was less $30 \%$, it indicated the need to create new green open spaces, especially public green non-natural open spaces in wellscale residential areas Districts and Urban village (kelurahan) both in the form of elongated linear green open spaces and centralized green open spaces. When seen in detail in table 2 about the area of green open space by type, the broad composition of green lane roads in the whole city of Kendari was the biggest part. Then followed by the Green Road Path and the Green Beach Path. This identified that linear green open spaces along the road and the coast were still in good condition so that they could support the ecosystem and ecology of the city. From the table it could be seen also the difference between the RTRW direction in Kendari and the reality was still not enough to meet the specific expectations for the area of Nature Tourism Park which still lacked 2090 hectares.

\section{b. Wide Area of Green Open Space and Urban Heat Island in Kendari}

Development in urban areas causes a lack of open areas, especially green open spaces. Availability of green open space in urban areas also determines the temperature in the area. The greater the area of green open space, the lower the temperature, and on the other hand the narrower the area of green open space the higher the temperature. Area with high air temperature was required to increase the open space green to reduce the temperature of the surrounding air.

Baruga District, which had the largest open space in Kendari with an area of $38.96 \mathrm{~km}^{2}$, was a residential development area and health facility. The increase in the development of both residential areas and supporting infrastructure could increase the surface temperature of the area as shown in Figure 1. Unlike the case with the District of Baruga, Kadia Subdistrict covered an area with the second smallest RTH after West Kendari. Along with the development of the Kadiam Subdistrict area being the municipal office area without being offset by the availability of green open space on the office scale, the temperature of the region could be seen as shown in Figure 2, had a decreasing area of green open space as a result of 
the development in this region which did not take into account the availability of green space so that the more built-up areas could increase urban temperature in the highlands. Even though green open space in this area was spread at various points, it was still not able to reduce the surface temperature of the surrounding area so that during the daytime in areas that lack shade vegetation it felt hot.
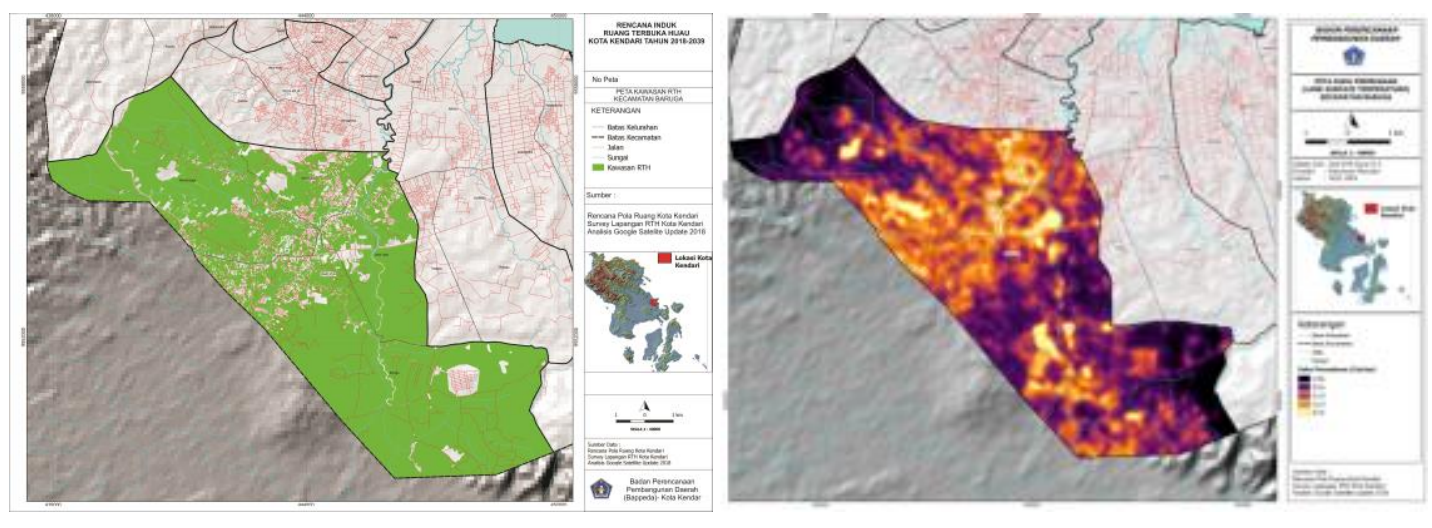

\author{
Fig 1. Green Open Space Area in Baruga \\ District and results of Urban Surface \\ Temperature analysis \\ Source: Kendari Green Open Space Survey \\ and GIS analysis - Urban Surface \\ Temperature, 2018
}

Based on Figure 1 in Baruga Sub district, it could be seen that the trend of bright colors could be seen in parts of urban areas which did not have green open space, in the form of areas with darker color indicators indicating the extent and condition of open green space very well with very good oxygen and cooling area. Green open space through the transpiration process effectively uses a latent heat so that it minimizes the use of energy to heat up the air (sensible heat). Consequently on high vegetation land tended to feel cooler. Therefore, it was highly recommended that each city had to have $40 \%$ of its total area or equivalent 20 large trees every $4000 \mathrm{~m}^{2}$. The calculation was based on the calculation of energy balance, which was the conversion of net radiation was more widely used for latent heat, thus reducing the portion of sensible heat, so that it would be more effective if the green space area was $40 \%$ of the city. High temperatures were characteristic of the urban air condition, thus created a city microclimate [4]. The temperature difference between the city and the surrounding area is called Urban Heat Island (UHI) [5] gives an influence on the comfort level of the city as Kendari had a vision and mission as a Livable City. Was an example of climate modification that accidentally happened due to human activities [5]. Many actors influence the occurrence of UHI phenomena. In general these factors include meteorology, location, and characteristics of the city.

Through a combination of air cooling and cooling through tranpiration, green open space could be used to prevent UHI from developing urban areas. During the vegetation area during active growth, the rate of $\mathrm{CO}_{2}$ absorbed through photosynthesis was much greater than the $\mathrm{CO}_{2}$ released rate in the respiration process, so the end result was a decrease in $\mathrm{CO}_{2}$ in the atmosphere so that it indirectly prevented global warming. 

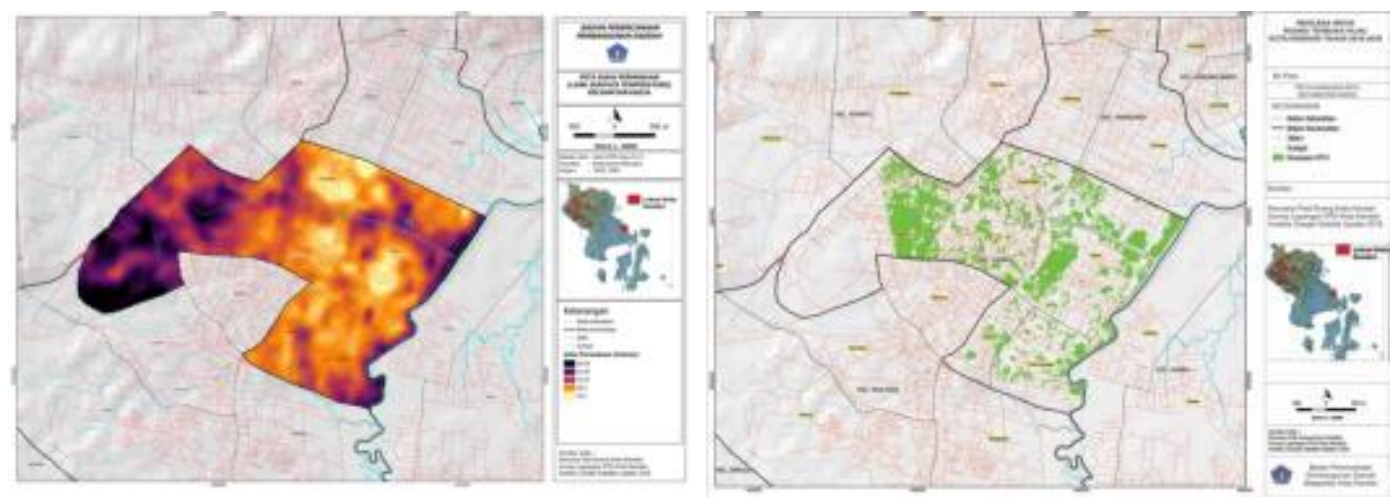

Fig 2. Green Open Space Area in Abeli District and results of Urban Surface

Temperature analysis

Source: Kendari Green Open Space Survey, 2018

In Figure 2, the following was an illustration of the area and distribution of open green space in the Kadia Subdistrict area, which was the center of the Kendari office area, as well as visible temperature conditions in the region. As previously explained, Kadia Sub-district had an area of RTH less than $30 \%$ of its sub-district area. It is seen that the condition of high surface temperatures is almost evenly distributed specifically in the built-up area (offices) that had high building density. Most of the buildings were office and service areas spread in Kadia District.
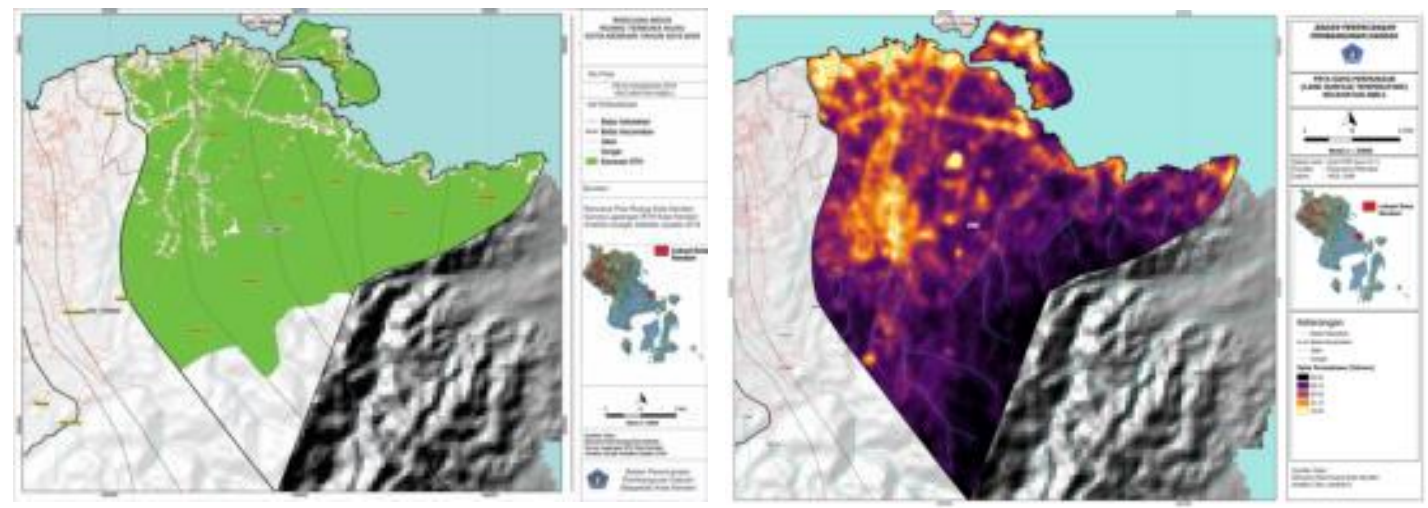

Fig 3. Green Open Space Area in Abeli District and results of Urban Surface Temperature analysis Source: Kendari Green Open Space Survey and GIS analysis - Urban Surface Temperature, 2018 
Meanwhile, in Figure 3, Abeli Sub-district which had an area of open green space that took very adequate and supported by the condition of a good production forest area on the South side, could reduce the intensity of the regional temperature. This was indicated by the extent of the forest in the Benua Nirae Village to Sambuli which was still quite extensive and maintained. Although, at some points in the built area it can be seen that the temperature is still high, but generally with adequate green open space conditions it can cool the air temperature in around it.

Based on the comparison of Kadia and Abeli sub-districts, it could be clearly seen that the importance of green open space in an area is to reduce the heat around the area. The availability of RTH must be maximized in the built areas in Kendari, especially areas with high building densities, such as the central area. offices, settlements and commercial areas in the city. Provision of new RTH is needed in Abeli Sub-district to reduce high surface temperatures in the form of green open space in the form of Urban Forests and RTH of City Parks in areas that were representative and easily accessible.

\section{Conclusion}

The quality of green open space is directly proportional to the wide availability and condition of green open space, the better the quality and condition of urban green space, the lower the surface temperature of an area will also be better (it tends to be cold/ cool). The wider and better the green space condition, the better the ability to cool an area and vice versa so that it can reduce / inhibit the formation of the Urban Heat Island effect. Provision of green open space in densely populated areas is needed to cool the thermal temperaturef the region. From this research, it can help give consideration to the Regional Government of Kendari to provide new open green space, especially in Kadia District. This research can be developed to a more detailed stage such as the influence of vegetation type and density on its ability to cool surface temperature.

\section{References}

[1] RPJMD Kota Kendari. Badan Perencanaan dan Pembangunan Kota Kendari, 2018.

[2] Branch, M.C.: Perencanaan Kota Komprehensif Pengantar dan Penjelasan. Edisi Terjemahan. Yogyakarta: Gajah Mada University Press, 1996.

[3] US. EPA (U.S. Environmental Protection Agency). Condition of the Mid-Atlantic Estuaries. EPA/600/R-98/147. Office of Research and Development, U.S. Environmental Protection Agency, Washington, DC, USA., 1998.

[4] Baik, J. J., Kim, Y. H., Kim, J. J., \& Han, J. Y.. Effects of Boundary-Layer Stability on Urban Heat Island-Induced Circulation. Theoretical adn Applied Climatology, 89 , 73 81, 2007.

[5] Oke, T. R.. Boundary Layer Climate. London: Methuen \& Co. Ltd., 1977. 